\title{
Design and construction a didactic vending machine
}

\section{Diseño y construcción de maquina vending didáctica}

\author{
MORALES-AGUILAR, Eric*†, SANTILLAN-FLORES, Selma E., GONZÁLEZ-LÓPEZ., Juan M. \\ and VILLALVAZO-LAUREANO, Efrain
}

Universidad de Colima. Avenida Universidad 333, Las Víboras, 28040 Colima, Col.

ID $1^{\text {st }}$ Author: Eric, Morales-Aguilar / ORC ID: 0000-0002-3970-8298, CVU CONACYT ID: 225102

ID $1^{\text {st }}$ Coauthor: Selma E., Santillan-Flores / ORC ID: 0000-0003-4935-4136, CVU CONACYT ID: 1034822

ID $2^{\text {nd }}$ coauthor: Juan M., González-López / ORC ID: 0000-0002-1795-3903, CVU CONACYT ID: 211801

ID $3^{\text {rd }}$ Coauthor: Efrain, Villalvazo-Laureano / ORC ID: 0000-0002-5939-7503, CVU CONACYT ID: 428346

DOI: $10.35429 /$ JCSI.2020.17.6.15.22

Received January 25, 2020; Accepted June 15, 2020

\begin{abstract}
This paper proposes the design and construction of a didactic vending machine, students pretend to be immersed in a work with delivery date as many companies that work for projects do. The project of vending machine to be developed will have as parameters that dispatch four different products, with a control panel, a $16 \times 2$ LCD screen which shows the cost of the chosen product or product, will have to give change and its data processing is via Arduino, a 3D simulation is carried out to ensure the compatibility of all components, an innovation presented by the prototype to be developed is that it sends a text message when a product is about to run out, with the product description, the number of machine and its location, this provides the supplier with better control over their large-scale machines. A comprehensive financial investment analysis is performed to ensure the viability of the project.
\end{abstract}

Vending Machine, Arduino, Autonomous Communication

\begin{abstract}
Resumen
En este artículo se propone el diseño y construcción de una máquina vending didáctica, los estudiantes simulan estar inmersos en un trabajo con fecha de entrega como lo realizan muchas empresas que trabajan por proyectos. El proyecto de máquina vending a ser desarrollada tendrá como parámetros que despache cuatro diferentes productos, con un panel de control, una pantalla LCD 16 x 2 el cual muestre el costo del producto o producto elegido, tendrá que dar cambio y su procesamiento de datos es vía Arduino, se realiza una simulación 3D para asegurar la compatibilidad de espacio de todos los componentes, una innovación que presenta el prototipo a desarrollar es que manda un mensaje de texto cuando algún producto está por agotarse con la descripción del producto, el número de máquina y su ubicación, esto le proporciona al proveedor tener un mejor control sobre sus máquinas a gran escala. Se realiza un análisis integral de inversión financiera para garantizar la viabilidad del proyecto. del proyecto.
\end{abstract}

Máquina Vending, Arduino, Comunicación Autónoma

Citation: MORALES-AGUILAR, Eric, SANTILLAN-FLORES, Selma E., GONZÁLEZ-LÓPEZ., Juan M. and VILLALVAZO-LAUREANO, Efrain. Design and construction a didactic vending machine. Journal of Computational Systems and ICTs. 2020. 6-17: 15-22.

\footnotetext{
* Author Correspondence (E-Mail: emorales@ucol.mx)

$\dagger$ Researcher contributing as first Author.
} 


\section{Introdution}

The world of vending machines has been a big business since the 1880 s, which sold postcards, until today, some have refrigeration and / or internal heaters, which make them able to sell practically anything (Burguete, 2015) Some even have security systems to supply restricted access products by means of digital identification (Calvo \& Latorre, 2013), they are manufactured in multiple sizes depending on the expected sales volume or available space (Vendomatica, 2007), you can choose for two sales models: the first is that the machine is operated by the brand owner or the second is that an individual buys and installs a machine in their business, (Chévez \& Adrianzén, 2019). Others carry out marketing plans with the aim of opening the market and positioning their brand, strengthening distribution in sales channels, advertising and promotion (Milena García, Monje Maca, \& Rodríguez, 2020). Currently, vending machines accept different forms of payment such as coins, bills and even credit and / or debit cards and it is expected that in the near future they will accept payment with smartphone applications (Gavilanes, 2018). Even in some works, the feasibility and business potential provided by small and large-scale vending machines (Carrillo, 2008), (Figueroa, 2018) is minimally reviewed, carrying out an analysis of the area, a study of a machine according to their present needs in the area (Castro Flores \& Mejia Vargas, 2020), programming the action in the sale based on defined commercial parameters and their positioning (Innovation and Qualification \& Torres Gómez, 2020).

Observing the potential and relevance of the vending machine, works in universities have been developed with the aim that their students develop the potential to build and operate them as a complementary part of their training or as thesis work to obtain a degree, within the Which is included, the approach is given as a business based on a theoretical foundation under established parameters and standards, formulating a situational diagnosis of the emerging needs and requirements in the market (Rojas Cabrera, 2020). Some works propose a project with a commitment to the environment and sustainable development, providing the opportunity for the installation site to educate themselves on knowledge (Romero Pascual, 2020).
On the other hand, currently, several works have been carried out in monitoring vending machines which give various data such as the last recharge date, the number of items sold and the estimated date of next recharge with geolocated GPS applications (Matute \& Uday, 2013), another includes logistic processing with internet via Wifi (Ramírez, 2018, pp. 25-30), including storage in "the cloud", allowing space to be saved on computer servers (Walid, Sigit, \& Sritrusta, 2019) and (Boces \& Boces, 2015). The disadvantage of this type of communication is that you do not always have Wi-Fi internet connectivity in the places of installation or it can be expensive to implement your own internet system. On the other hand, storing the data in "the cloud" requires a web page or service provider which requires a monthly or annual rental, which makes monitoring more expensive. In this sense, the prototype set out in this article is to build a didactic vending machine as a complement to the studies in Electronics Engineering, the machine shown here dispatches only four products and can be expanded to an industrial size if necessary, in addition to complying with all the functions of an industrial vending machine.

On the other hand, an innovation that is proposed is the remote monitoring of the product available via text message to the supplier, which incorporates the number of products available, the number of the machine and its location, as it is a text message practically throughout the territory there is a signal provided by Telcel (Mexico) in addition to its relative low cost compared to the machines that occupy satellite internet.

\section{App software}

The detailed logic of the implemented program is visualized in the flowchart of Figure 1 and can be briefly described in the following steps:
1).- Active and waiting
2).- Receive money
3).- Product selection
4).- Available product, enough money and enough change?

5).- Dispatch product 
6).- Deliver surplus money (change).

\section{7).- Go back to step one.}

It should be noted that if any of the previous steps is negative, it will return to the previous one showing the reason on an LCD screen located in front of the machine. On the other hand, if there are no exchange currencies in the purse, a legend "insert exact amount" appears, forcing the user to deposit the exact amount calculating change equal to zero and allowing it to continue through the flow chart of Figure 1. A probable external risk is the jamming of the product in the delivery spirals, to avoid this problem, a presence sensor is incorporated where the products fall from the spirals, which detects the fall of the product and sends a signal to continue with the sales process, this step is incorporated into the program within step 5 described in this section.

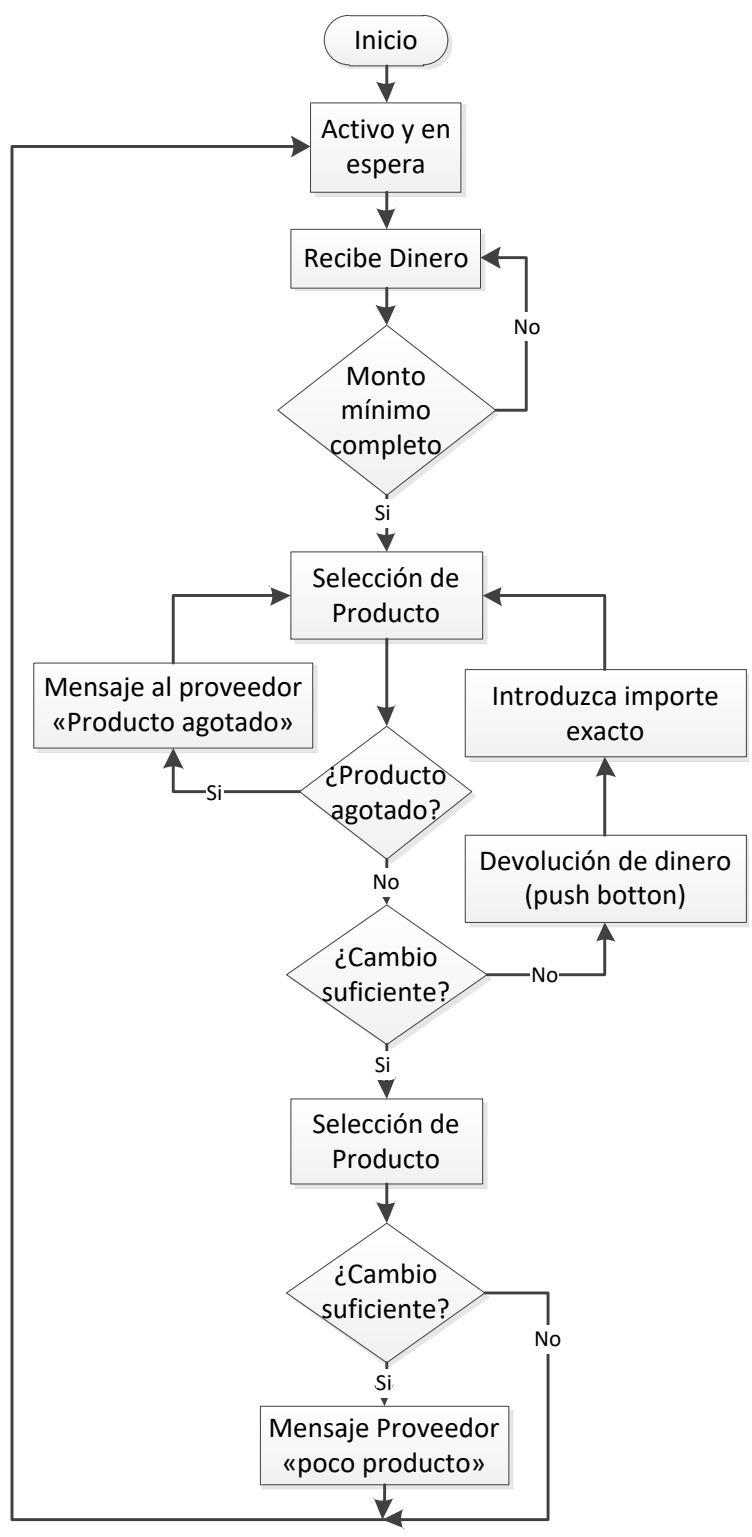

Figure 1 Vending machine operation logic
Internally, the program is designed so that when it has "little" product, it sends a text message with the product description, the machine number and its location, this is done using the "4GS GPSR Module" which is compatible with Arduino and is powered by a SIM card with the company TELCEL de México, it should be noted that this card recharges like any mobile phone. In this case, 2 pieces were determined, although the data can be adjusted according to the supplier's response time and dispatch frequency. The entire program is in an infinite loop so always after a completed transaction you will return to step 1 to wait for another client. In addition, it has an operation cancellation button so that the client can cancel the purchase and obtain the refund of the inserted money.

Next, with the software logic that you want to follow described above, it is programmed in Proteus to perform the complete operation simulation and debug errors, the complete design is shown in Figure 2, it is sectioned into 6 main devices identified by the number circled in Figure 2.

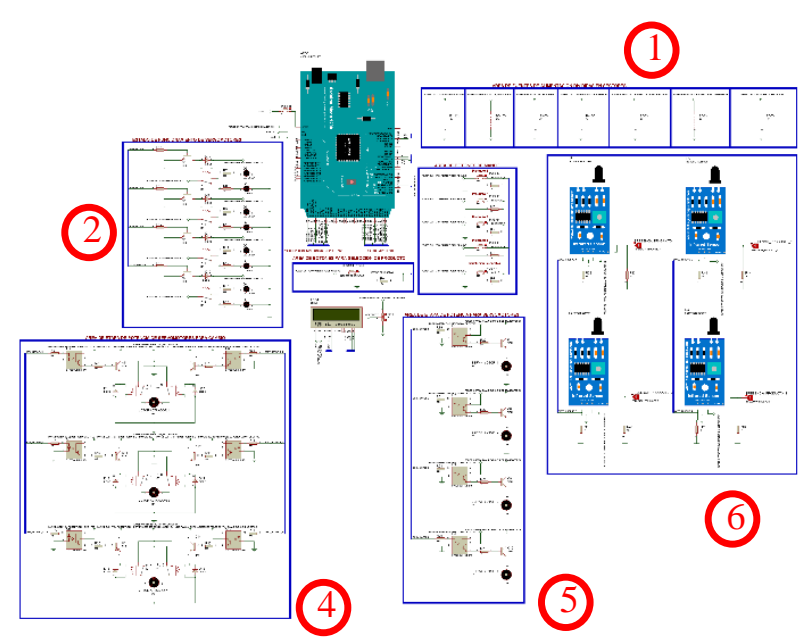

Figure 2 Proteus prototype design

Within Figure 2 the main functions of each section are as follows:

Section 1).- Power supplies for all sections of the vending machine.

Section 2).- Review circuit of the operation of servo-motors.

Section 3) .- Control buttons area. 
Section 4) .- Circuit for backward and forward movement of the actuator (Product dispatcher).

Section 5) .- Electronic diagram for motor drive dispatches product

Section 6).- Simulated representation of obstruction sensors for product counting.

\section{Hardware Design}

After having tested the logic of the program, as well as its implementation in the virtual environment of the Proteus software, we first proceed to provide a $3 \mathrm{D}$ view of the circuit (see Figure 3) to obtain measurements and a preliminary view of the device to be built.

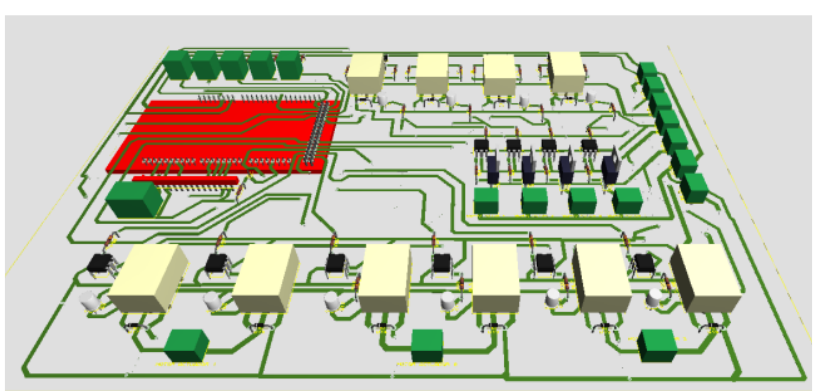

Figure 3 3D view of the circuit to implement

Then the printed electronic circuit shown in Figure 4 is designed with the support of the Lives Wire and PCB Wizard software and printed by the ironing method.

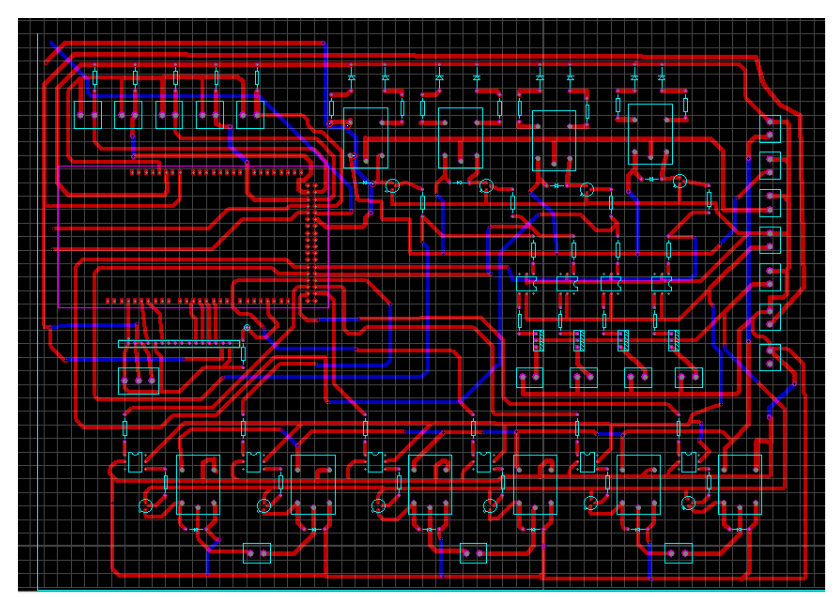

Figure 4 Design of the tracks of the printed electronic circuit

Once the printed circuit is obtained, all the elements are assembled according to the sketch in Figure 3. A view of the final implementation of the circuit is shown in Figure 5.

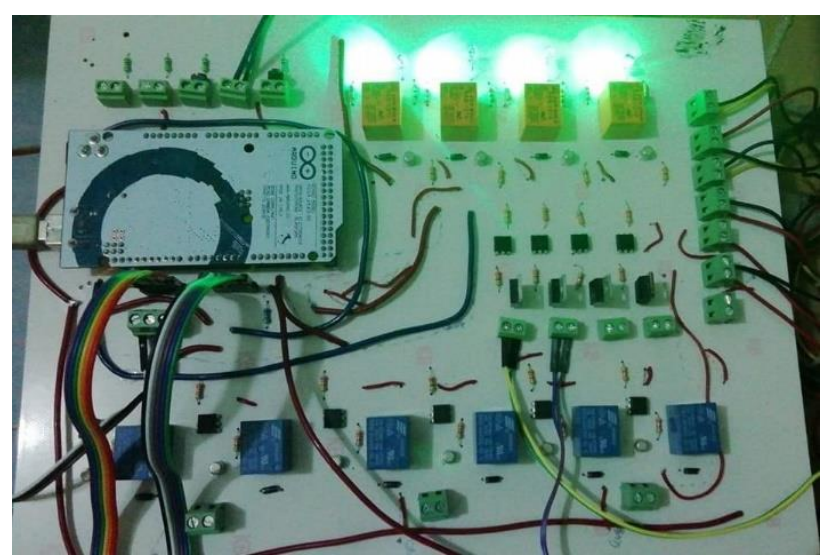

Figure 5 Printed circuit view

On the other hand, the machine casing is designed taking into account all the dimensions of the internal elements, this stage is crucial because if any element does not fit in the intended place, it could lead to a total redesign of the casing. Detailed plans are presented in Figure 6.
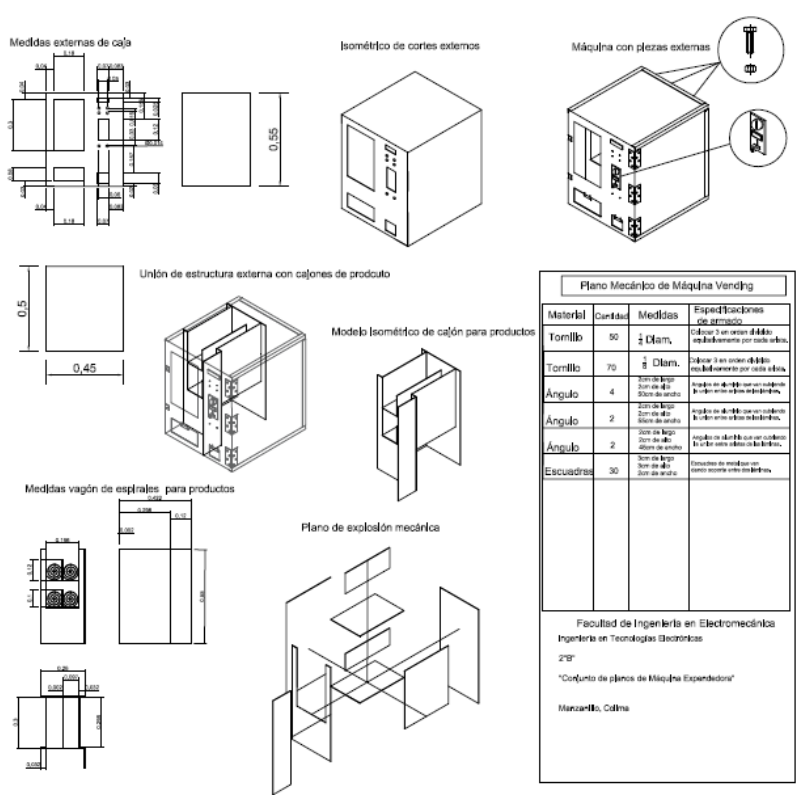

Figure $63 \mathrm{D}$ plans of the vending machine casing

For a better visualization of the planes exposed in Figure 6 an enlarged view of the 3D design with transparencies in isometric is shown in Figure 7. 


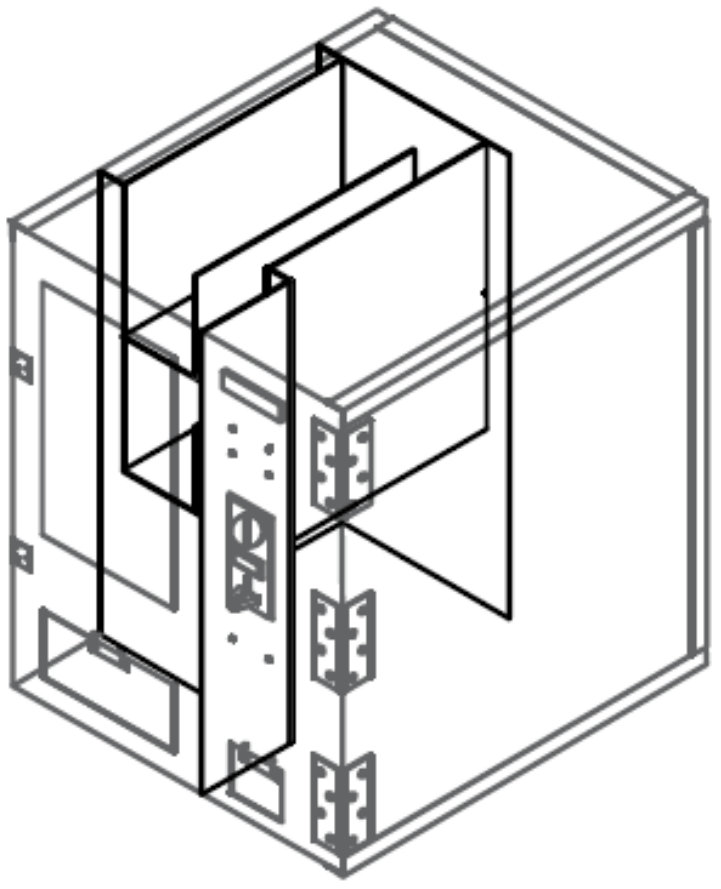

Figure 7 Isometric view with 3D transparencies of the Vending machine

\section{Torque Required in Spirals}

To verify that the spirals do not get stuck with the product due to its weight, the minimum necessary torque of the servomotor is calculated considering the following parameters:

- $\quad$ Maximum weight of each product $=0.250$ $\mathrm{kg}$

- $\quad$ Maximum number of products per spiral $=$ 6

- $\quad$ Spiral weight $=0.5 \mathrm{~kg}$

- $\quad$ Spiral radius $=5 \mathrm{~cm}$

With these data, the maximum gross weight that is moved when a product is dispatched is calculated using Eq. one.

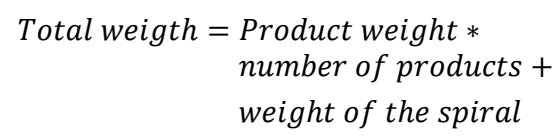

Substituting the data in Eq. 1 we obtain:

Total weigth $=0.25 * 6+0.5=2 \mathrm{~kg}$

To calculate the torque force you need for a wheel with a radius of $5 \mathrm{~cm}$ and a weight of $2 \mathrm{~kg}$, it can be done using Eq. 2

$F=\frac{\mathrm{kg}}{\mathrm{cm}}$
Substituting the respective values in eq. 2 you get:

$F=\frac{2}{5}=0.4 \mathrm{~kg} / \mathrm{cm}$

For the development of this project, the commercial servomotor Model MG995 with a torque of $10 \mathrm{~kg} / \mathrm{cm}$ is selected, which clearly provides a torque greater than the minimum required, thus ensuring proper rotation.

\section{Complete assembly}

Finally, it is carried out in assembly of all the internal and external elements of the designed Vending machine, the biggest problem presented was the jamming of the product in the ejector system (an "endless" spiral) which was efficiently solved by increasing the diameter of the mechanism. A final view of the prototype made is presented in Figure 8.

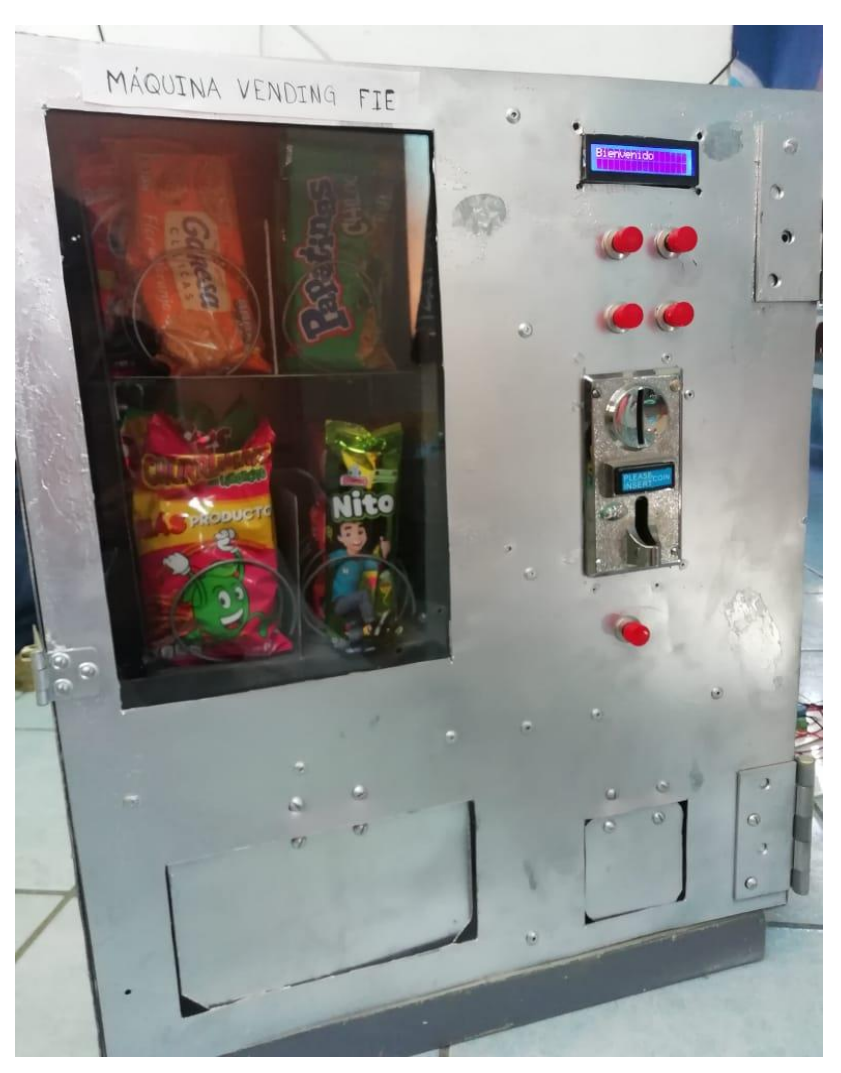

Figure 8 Vending machine designed and built

MORALES-AGUILAR, Eric, SANTILLAN-FLORES, Selma E., GONZÁLEZ-LÓPEZ., Juan M. and VILLALVAZOLAUREANO, Efrain. Design and construction a didactic vending machine. Journal of Computational Systems and ICTs. 2020 


\section{Investment in the Prototype}

\section{Hours, man}

The prototype presented in this article is made over a semester, on average, 12 hours per week were invested, having a total of 1872 man hours. The students are divided into 3 subgroups that, as far as possible, progressed in parallel to make construction more efficient. These subgroups are:

1) Design and construction of the interior of the machine.

2) Software design in Proteus and Arduino.

3) Quotation, purchases and implantation (hardware) of electronic devices.

\section{Material Cost}

Firstly, the complete list of the necessary elements is analyzed, and the most appropriate ones to be implemented are studied: they comply with the requirements of the project at a lower price.

The items generally and in an increasingly globalized world were ordered through the internet with a waiting time of up to a week, which due to the times handled is a good option. It should be noted that an incentive to optimize cats was for students to absorb the initial cost of the materials. Table I shows the complete list of materials used giving a total of \$ 8,073.20 Mexican pesos.

\begin{tabular}{|l|l|l|l|l|}
\hline Description & \multicolumn{1}{|l|}{ Unit } & Quantity & P.U & Amount \\
\hline Aluminum sheets & $\mathrm{kg}$ & 25 & $\$ 21.00$ & $\$ 525.00$ \\
\hline Spiral wire & $\mathrm{Kg}$ & & $\$ 45.00$ & $\$ 45.00$ \\
\hline Reelevator module & $\mathrm{Pc}$ & 1 & $\$ 90.00$ & $\$ 90.00$ \\
\hline $\begin{array}{l}\text { Generic Arduino } \\
\text { Mega (wired) }\end{array}$ & $\mathrm{Pc}$ & 1 & $\$ 320.00$ & $\$ 320.00$ \\
\hline LCD screen (2x16) & $\mathrm{Pc}$ & 1 & $\$ 100.00$ & $\$ 100.00$ \\
\hline Aluminum angles & $\mathrm{m}$ & 8 & $\$ 28.00$ & $\$ 224.00$ \\
\hline $\begin{array}{l}\text { TowerPro MG995 } \\
\text { 15kg / cm servo } \\
\text { motor }\end{array}$ & $\mathrm{Pc}$ & 4 & $\$ 160.00$ & $\$ 640.00$ \\
\hline Power supply & $\mathrm{Pc}$ & 1 & $\$ 250.00$ & $\$ 250.00$ \\
\hline $\begin{array}{l}\text { Electronic } \\
\text { Multicurrency } \\
\text { Selector }\end{array}$ & $\mathrm{Pc}$ & 1 & $\$ 750.00$ & $\$ 750.00$ \\
\hline SG90 Mini Servo & $\mathrm{Pc}$ & 4 & $\$ 65.00$ & $\$ 260.00$ \\
\hline Male pin strips & $\mathrm{Pc}$ & 4 & $\$ 10.00$ & $\$ 40.00$ \\
\hline Potentiometer 1M & $\mathrm{Pc}$ & 2 & $\$ 9.00$ & $\$ 18.00$ \\
\hline Colored LEDs & $\mathrm{Pc}$ & 10 & $\$ 1.00$ & $\$ 10.00$ \\
\hline $\begin{array}{l}\text { Transistor } \\
\text { 2N2222A }\end{array}$ & $\mathrm{Pc}$ & 4 & $\$ 30.00$ & $\$ 120.00$ \\
\hline $\begin{array}{l}\text { Optocoupler 4N25 } \\
\text { NPN }\end{array}$ & $\mathrm{Pc}$ & 10 & $\$ 9.50$ & $\$ 95.00$ \\
\hline Compact relay & $\mathrm{Pc}$ & 4 & $\$ 30.00$ & $\$ 120.00$ \\
\hline Varied resistances & $\mathrm{Pc}$ & 45 & $\$ 1.20$ & $\$ 54.00$ \\
\hline $\begin{array}{l}\text { Terminal Block } 3 \\
\text { poles }\end{array}$ & $\mathrm{Pc}$ & 22 & $\$ 9.30$ & $\$ 204.60$ \\
\hline
\end{tabular}

ISSN-2444-5002

ECORFAN $^{\circledR}$ Todos los derechos reservados

\begin{tabular}{|c|c|c|c|c|}
\hline 26 way cable & $\mathrm{m}$ & 2 & $\$ 48.00$ & $\$ 96.00$ \\
\hline Diode 1N4007 & $\mathrm{Pc}$ & 4 & $\$ 3.10$ & $\$ 12.40$ \\
\hline Switch Push Button & $\mathrm{Pc}$ & 6 & $\$ 35.50$ & $\$ 213.00$ \\
\hline $\begin{array}{l}\text { MOC } \\
\text { Integrated Circuit }\end{array}$ & $\mathrm{Pc}$ & 7 & $\$ 22.00$ & $\$ 22.00$ \\
\hline $\begin{array}{l}\text { Terminal Block } 2 \\
\text { poles }\end{array}$ & $\mathrm{Pc}$ & 20 & $\$ 9.10$ & $\$ 182.00$ \\
\hline $\begin{array}{l}\text { Phenolic Plate } 30 \mathrm{x} \\
30\end{array}$ & $\mathrm{Pc}$ & 1 & $\$ 199.50$ & $\$ 199.50$ \\
\hline $\begin{array}{ll}\begin{array}{l}\text { Circuit } \\
\text { sheets }\end{array} & \text { transfer } \\
\end{array}$ & Pack. & 1 & $\$ 75.00$ & $\$ 75.00$ \\
\hline Mini drill bits & Pack. & 1 & $\$ 99.00$ & $\$ 99.00$ \\
\hline $\begin{array}{l}\text { Normal drill bits } \\
\text { (assorted size) }\end{array}$ & Pc. & 8 & $\$ 10.00$ & $\$ 80.00$ \\
\hline $\begin{array}{l}\text { PBC tubes } \\
\text { (assorted size) }\end{array}$ & $\mathrm{m}$ & 2 & $\$ 18.00$ & $\$ 36.00$ \\
\hline Riveter & $\mathrm{Pc}$ & 1 & $\$ 90.00$ & $\$ 90.00$ \\
\hline $\begin{array}{l}\text { Silicone placement } \\
\text { gun for aluminum }\end{array}$ & $\mathrm{Pc}$ & 1 & $\$ 50.00$ & $\$ 50.00$ \\
\hline Silicone & $\mathrm{Pc}$ & 2 & $\$ 35.00$ & $\$ 70.00$ \\
\hline Rivets & Pack. & 3 & $\$ 20.00$ & $\$ 60.00$ \\
\hline Hinge & $\mathrm{Pc}$ & 3 & $\$ 20.00$ & $\$ 60.00$ \\
\hline Brackets & Par & 12 & $\$ 3.00$ & $\$ 36.00$ \\
\hline Nuts & $\mathrm{Pc}$ & 30 & $\$ 0.30$ & $\$ 10.00$ \\
\hline Screws & $\mathrm{Pc}$ & 30 & $\$ 0.50$ & $\$ 15.00$ \\
\hline Painting & Can & 7 & $\$ 55.00$ & $\$ 385.00$ \\
\hline Metal cutting discs & $\mathrm{Pc}$ & 3 & $\$ 15.00$ & $\$ 45.00$ \\
\hline Sandpaper & $\mathrm{Pc}$ & 5 & $\$ 8.00$ & $\$ 40.00$ \\
\hline Black tape & $\mathrm{Pc}$ & 1 & $\$ 15.00$ & $\$ 15.00$ \\
\hline $\begin{array}{l}\text { TCRT5000 } \\
\text { infrared } \\
\text { sensor }\end{array}$ & Pc & 4 & $\$ 35.00$ & $\$ 140.00$ \\
\hline Electric actuator & $\mathrm{Pc}$ & 3 & $\$ 38.00$ & $\$ 112.00$ \\
\hline $\begin{array}{l}\text { GSM GPSR } 4 \mathrm{G} \\
\text { module }\end{array}$ & $\mathrm{Pc}$ & 1 & $\$ 660.00$ & $\$ 660.00$ \\
\hline $\begin{array}{l}\text { Phenolic Plate } 30 x \\
30\end{array}$ & $\mathrm{Pc}$ & 1 & $\$ 199.5$ & $\$ 199.5$ \\
\hline Aluminum foil & $\mathrm{kg}$ & 1.4 & $\$ 18.00$ & $\$ 25.00$ \\
\hline Potentiometer $1 \mathrm{M}$ & $\mathrm{Pc}$ & 2 & $\$ 9.00$ & $\$ 18.00$ \\
\hline Colored LEDs & $\mathrm{Pc}$ & 10 & $\$ 1.00$ & $\$ 10.00$ \\
\hline $\begin{array}{l}\text { Transistor } \\
\text { 2N2222A }\end{array}$ & $\mathrm{Pc}$ & 10 & $\$ 25.00$ & $\$ 250.00$ \\
\hline Compact relay & $\mathrm{Pc}$ & 10 & $\$ 22.00$ & $\$ 220.00$ \\
\hline Varied resistances & $\mathrm{Pc}$ & 46 & $\$ .5$ & $\$ 23.00$ \\
\hline 26 way cable & $\mathrm{m}$ & 4 & $\$ 25.00$ & $\$ 100.00$ \\
\hline Diode 1N4007 & $\mathrm{Pc}$ & 12 & $\$ 3.10$ & $\$ 31.20$ \\
\hline $\begin{array}{l}\text { Optocoupler } 4 \mathrm{~N} 25 \\
\text { npn }\end{array}$ & $\mathrm{Pc}$ & 10 & $\$ 12.00$ & $\$ 120.00$ \\
\hline $\begin{array}{l}\text { Screws, nuts, } \\
\text { angles, tin, paint } \\
\text { etc. }\end{array}$ & Various & NA & NA & $\$ 280.00$ \\
\hline Ferric Acid & $\mathrm{Pc}$ & 1 & $\$ 40.00$ & $\$ 40.00$ \\
\hline Terminal block & $\mathrm{Pc}$ & 10 & $\$ 4.00$ & $\$ 40.00$ \\
\hline $\begin{array}{l}\text { Compressed } \\
\text { cardboard }(30 \times 40) \\
\text { and }(25 \times 30)\end{array}$ & Pc & 2 & $\begin{array}{l}\$ 35.00 \\
\$ 23.00\end{array}$ & $\$ 58.00$ \\
\hline Tip 41 & $\mathrm{Pc}$ & 4 & $\$ 8.00$ & $\$ 32.00$ \\
\hline Metal prisms & $\mathrm{kg}$ & 1 & $\$ 60.00$ & $\$ 60.00$ \\
\hline Arduino Mega & Pc & 1 & $\$ 300.00$ & $\$ 300.00$ \\
\hline $\begin{array}{l}\text { Duponds male- } \\
\text { male, male-female }\end{array}$ & Pack. & 3 & $\$ 45.00$ & $\$ 135.00$ \\
\hline \multicolumn{5}{|c|}{ Total } \\
\hline
\end{tabular}

Tabla 1 Material Requerido para La construcción de Máquina Vending

\section{Acknowledgments}

The authors thank the Faculty of Electromechanical Engineering of the University of Colima, Manzanillo campus for granting the facilities for the presentation of this work.

MORALES-AGUILAR, Eric, SANTILLAN-FLORES, Selma E., GONZÁLEZ-LÓPEZ., Juan M. and VILLALVAZOLAUREANO, Efrain. Design and construction a didactic vending machine. Journal of Computational Systems and ICTs. 2020 


\section{Conclusions}

The design and construction of a Teaching Vending Machine is presented in this work which shows to be of great help in expanding and implementing the knowledge acquired in classrooms such as project management, economics, electronics and / or programming.

Students develop their ability to work under objectives by dates, which is common in industries or better still, be an entrepreneur in project development.

\section{References}

Boces, \& Boces, D. (2015). Modelo Inteligente en la Nube para Maquinas Vending. (Tesis de Licenciatura). Universidad Politécnica de Madrid, Madrid, España.

Burguete, F. (2015). Máquina Vending de bebidas calientes. (Tesis de Licenciatura). Universidad Politecnica de Navarra, Pamplona, España.

Calvo, I., \& Latorre, J. (2013). Diseño De Una Máquina De Vending Para Suministrar Productos De Acceso General Y Otros De Acceso Restringido Por Medio De Identificación Digital. Tesis Licenciatura. Escuela Técnica Superior De Ingenieros Industriales Y De Telecomunicaciones, Panplona, España.

Carrillo, D. (2008). Estudio y Factivilidad del Diseño de una Maquina Dispensadorade Huevos en la Ciudad de Cartagena. (Tesis de licenciatura). Universidad Tecnológica de Bolivar, Cartagena, Colombia.

Castro Flores, E. J., \& Mejia Vargas, J. G. (2020). Diseño de una Máquina Portátil Trilladora - Venteadora de Cebada para el Centro Poblado de Cabracancha - Chota Cajamarca. Tesis de licenciatura . Universidad Señor de Sipán, Pimentel - Perú.

Chévez, K., \& Adrianzén, S. (2019). Diseño e Implementación de Prototipo de una Máquina Dispensadora de Cupckes para una Actividad Comercial Lucrativa en la Ciudad De Chiclayo. (Tesis de Licenciatura). Universidad Nacional Pedro Ruiz Gallo, Lambayeque, Perú .
Figueroa , M. (2018). El Gran Potencial de las Maquinas Vending; las Medidas a tu Alcance. (Tesis de Licenciatura). Escuela Superior de Comercio Internacional, Barcelona, España.

Gavilanes, S. (2018). Trabajo de titulación en la modalidad de Proyecto de emprendimiento previo a la obtención del Título de Ingeniero en Marketing y Gestión de Negocios. (Tesis de Licenciatura). Universidad Técnica de Ambato, Ambato, Ecuador .

Innovación y Cualificación, s., \& Torres Gómez, C. A. (2020). Organización de Procesos de Venta. COMT0411. Antequera España: IC Editorial.

Matute, V., \& Uday, S. (2013). Diseño y Desarrollo de un Sistema de Ubicación, Monitoreo y Control de una Maquina Vending Dispensadora de Bebidas Automática Mediante n Dispositivo AVL. (Tesis de Licenciatura). Universidad Ploitecnica Salesiana, Cuenca, Ecuador.

Milena García, M., Monje Maca, E. M., \& Rodríguez, A. P. (2020). Planteamiento de Expansión y Consolidación de la Marca Alpina en el Sector de Helados, Vía Plan de Marketing para Colombia. Tesis de Licenciatura. Universidad Rey Juan Carlos, Madrid, España.

Ramírez, D. (2018). Integración del internet de las cosas en los procesos logísticos de máquinas dispensadoras. Revista Cintex, 25-30.

Rojas Cabrera , E. R. (2020). Plan de negocios para la creación de un restaurante de comida fusión brasilera-portuguesa en la ciudad Ambato, provinicia de Tungurahua. Tesis de Licenciatura. Universidad Regional Autónoma de los Andes, Ambato, Ecuador.

Romero Pascual, L. E. (2020). Oficinas GBC Mediterráneo. Tesis de Maestria Universitario en Arquitectura. Universitad Politècnica de València, Departamento de Proyectos Arquitectónicos, Valencia, España.

Vendomatica, S. (2007). Fabricacion de una Máquina Vending con gran capacidad $y$ Variedad de Productos Frios y Calientes. Santiago, Chile: propia. 
Walid, M., Sigit, R., \& Sritrusta, S. (2019).

Vending Machine Monitoring System Integrated. International Electronics Symposium (págs. 556 - 559). Surabaya, Indonesia: IEEE. 